International Journal of Health Sciences
Available online at www.sciencescholar.us
Vol.5 No.3 December 2021, pages: 224-231
e-ISSN: 2550-696X, p-ISSN: 2550-6978
https://doi.org/10.53730/ijhs.55n3.1449

\title{
Community Nursing Strategies for Tourism Health Families during COVID-19 Pandemic
}

\author{
Aulia Asman a, Auzia Asman b, Anita Kusuma Dewi c
}

Manuscript submitted: 18 June 2021, Manuscript revised: 09 July 2021, Accepted for publication: 27 August 2021

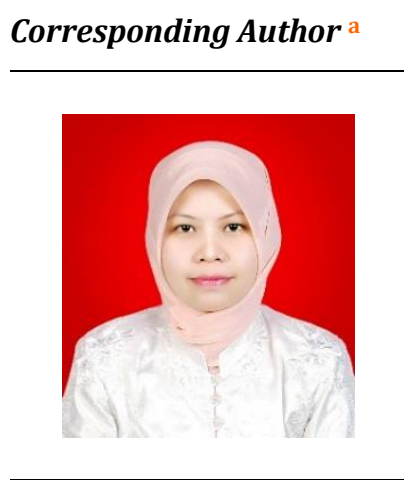

Keywords

COVID-19;

health protocol;

pandemic;

tourism health;

community nursing;

\begin{abstract}
Traveling during the COVID-19 pandemic to reduce boredom or stress due to staying at home, must continue to apply health protocols. However, there are still many people who are indifferent to these rules, causing community nurses to have a role and have the right strategy so that there will no longer be an increase in the positive number of COVID-19. This study aims to find out the right strategy carried out by community nurses for families doing tourism to continue to apply health protocols during the COVID-19 pandemic. This type of quantitative descriptive research is carried out through interviews and filling out questionnaires to expert respondents. The results of the questionnaire showing strategic priorities, paired comparisons were carried out which were analyzed using the Analytical Hierarchy Process (AHP) method. The results of the study, which was preceded by the determination of three indicators consisting of health, family, and tourism protocol, resulted in 7 alternative strategies. Of the seven alternatives, there are three strategic priorities in a row which consist of providing communication, information, and education (KIE) media regarding the prevention and control of COVID-19 in strategic locations in every tourist spot.
\end{abstract}

International Journal of Health Sciences (C) 2021. This is an open access article under the CC BY-NC-ND license (https://creativecommons.org/licenses/by-nc-nd/4.0/).

\section{Contents}

Abstract

1 Introduction.

2 Materials and Methods.

Results and Discussions

4 Conclusion

Acknowledgments..

References

Biography of Authors.

\footnotetext{
a Universitas Negeri Padang, Padang, Indonesia

b Politeknik Pertanian Payakumbuh, Payakumbuh, Indonesia

c Polteknik Negeri Lampung, Lampung, Indonesia
} 


\section{Introduction}

Since the spread of the COVID-19 virus in the world until the World Health Organization established a global emergency status, it is has raised awareness not only of the spread of the disease but the possible impact on the world economy. The COVID-19 outbreak has had an impact on international activities, such as the economy and various other activities. one of which is activities in the tourism sector (Berger, 2020). In Law Number 10 of 2009 concerning tourism, it is explained that tourism consists of various kinds of tourism activities and is supported by various facilities, as well as services provided by the community, businessmen, government and local governments, while tourism is a travel activity carried out by a person or group (Dryglas \& Salamaga, 2018). people by visiting certain places for recreational, personal development, or studying purposes the uniqueness of the tourist attraction visited in a temporary period. Before the COVID-19 outbreak, the tourism sector in 2020 was predicted to be the largest contributor to the country's foreign exchange in 2020, but this hope was suddenly lost due to the existence of COVID-19. As a result of the COVID-19 outbreak, many potential tourists have canceled visits to tourist attractions (ODTW) (UNWTOb, 2020). This is reinforced by a statement from the UNWTO (United Nation World Tourism Organization) (2020a) which estimates that international tourist arrivals may fall by $20 \%$ to $30 \%$ by 2020 (UNWTOa, 2020).

COVID-19 has caused people to remain at home, must always be vigilant by maintaining distance from each other and are advised to reduce travel (Kissler et al., 2020). Even though these conditions prevent people from traveling, it does not mean that this condition will last forever. The results show that after the area quarantine status or mobility restrictions are lifted, the community will continue to travel (Sayili et al., 2007). This aims to reduce the level of stress or boredom experienced by the community when there is a stay at home rule. In addition, tourism becomes a means of revenge or what is known as revenge travel or revenge travel.

This revenge tour is a tour carried out by tourists who have plans and are delayed due to COVID19 or revenge tours for limited freedom and want to go back out to visit tourist attractions and socialize like before the pandemic. Therefore, the government needs to prepare all tourism stakeholders to welcome the post-quarantine tourist wave. In connection with the strong desire of the community to do tourism, strategic steps have been taken by UNWTO and WHO (UNWTO, 2020a). Apart from UNWTO and WHO, the government has also started to implement policies, especially in tourist locations to avoid the new COVID-19 spread cluster. But in fact, it took quite a long time to allay the concerns of potential tourists regarding the transmission of the virus in a crowd (Mufti, 2020). Therefore, community nurses are needed to help families who are still worried about traveling or families who want to travel.

Community nurses are nurses providing a form of professional service based on nursing knowledge and tips aimed primarily at high-risk groups to improve community health status by emphasizing efforts to improve health, prevent disease and not neglect curative and rehabilitative (Betony \& Yarwood, 2013). From this understanding, it is known that this community nurse aims to maintain public health together with other professionals and work more closely with community members (Jansen et al., 1996; Hussin et al., 2021). This makes the role of community nurses to deliver health education or promotion very large and more heard by the public. With the potential for revenge travel, it is hoped that the community nurse will have a strategy for families who are going on trips or tours, which will have the potential to meet many people. Therefore, community nurses must have a strategy for families who are going to travel to stay healthy during the COVID-19 pandemic (Clase et al., 2020; Campbell, 2020). Thus, this study aims to develop a community nursing strategy for the family for tourism health during the COVID-19 pandemi.

Asman, A., Asman, A., \& Dewi, A. K. (2021). Community nursing strategies for tourism health families during COVID-19 pandemic. International Journal of Health Sciences, 5(3), 224-231. https://doi.org/10.53730/ijhs.v5n3.1449 


\section{Materials and Methods}

In developing a strategy, a quantitative descriptive study was conducted using data collection techniques, interviews with expert respondents and literature studies. Furthermore, using a pairwise comparison questionnaire between the elements at each level in order to obtain a hierarchical structure, which is processed by expert choice, and analyzed using the Analytical Hierarchy Process (AHP) method (Saaty, 1993). According to Marimin (2005); Latifah (2005), AHP's working principles consist of hierarchical arrangement (decomposition), criteria and alternatives assessment (comparative judgment), priority determination (synthesis of priority), and logical consistency (local consistency). The basic concept of AHP is the use of a pairwise comparison matrix to produce relative weight values between criteria and alternatives. A criterion is compared with other criteria in terms of how important it is to achieving the goals above (Saaty, 1993).

\section{Results and Discussions}

Since the COVID-19 pandemic, various sectors in human life have decreased, including the tourism sector. A number of stimuli prepared by the government to revive the tourism sector were unable to stem the negative impact of COVID-19 (Ningsih et al., 2021). Since the COVID-19 pandemic, various sectors in human life have decreased, including the tourism sector. A number of stimuli prepared by the government to revive the tourism sector were unable to stem the negative impact of COVID-19. Facing this, various efforts have been made by the Indonesian government to save and accelerate the pace of Indonesia's economy in the tourism sector, besides that the tourism sector plays an important role in overcoming community saturation during this pandemic. Under normal conditions, there is a possibility that society may experience burnout (Asman et al., 2020; Asman \& Asman, 2021).

This saturation can be caused by factors of job loss due to staff reduction, loss of livelihoods, health workers who cannot meet with their families and large work demands, people who are at home also experience saturated, bored and stressed conditions (Asman, 2020; Lisbet, 2020). In dealing with the stress of this pandemic, it can be done by thinking realistically, being able to take lessons from the disaster, surrendering and praying (Asman \& Fatimah, 2020). Sharing, doing positive things, by involving families for excursions and obeying tourism health protocols of course (Sayili et al., 2007). This can be seen from the new normal tourism which is opened in several places, but still adheres to the prevailing health protocols in accordance with Ministerial Decree 02/KB/2020 and KB/1/UM.04.00/MK/2020 which was approved by the Minister of Tourism and Creative Economy with Minister of Education and Culture.

With the ratification of the decree, it encourages activists in the tourism sector to immediately open tourist objects and at the same time causes the Indonesian people who are already bored at home to want to do tourism activities. Given the importance of maintaining distance between tourists, local governments and related stakeholders also need to prepare supporting policies or regulations that can prevent crowding. Supporting this, education or health promotion is also provided to the community around tourist objects and tourism service entrepreneurs so that they can jointly monitor and comply with policies made to prevent the spread of the plague. This is to avoid panic and worry about the spread of COVID-19. In addition to the preparations made by the government, the community around tourist objects and tourism service entrepreneurs, families who are going to travel to tourist attractions must also understand the health protocol and the rules that have been set (Gunter et al., 2018; Foddai et al., 2020). If families or tourists do not know and understand it, then the potential spread of COVID-19 cannot be prevented. Health education or promotion can be carried out by community nurses. Despite the fact that community health nurses in Indonesia, especially those in health centers, do not carry out many professional duties for various reasons and problems (Swarjana, 2015). However, health education and promotion must still be provided to families or tourists. Therefore, to develop a community nurse strategy for families who will travel during a pandemic, 3 indicators are used consisting of health, family and tourism. These three indicators are analyzed for the level of consistency indicated by the small consintency ratio (CR) value of 0.1 , namely 0.04 which 
is shown in Figure 1. This assessment produces a weighted value for each element, as well as provides an overview of the priorities for each of these elements (Putri al., 2018; Ratiu \& Purcarea, 2015).

Priorities with respect to :

Goals : Strategy of community nurses in the family for tourism health
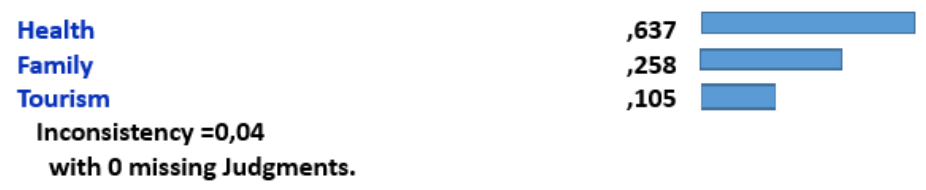

Figure 1. Value consistency criteria

Furthermore, after the established criteria are consistent, then an alternative policy or strategy is prepared related to each of these criteria. This alternative strategy is a strategy that can be carried out by the government and community caregivers, at the same time it can be applied in the family environment who will be doing tours during the COVID-19 period, as follows:

1) Evaluation of the health service program provided to the family.

2) Increasing coordination and cooperation of community nurses with local communities who live around tourist sites.

3) Direct checking and monitoring within a certain period of time for families doing tours.

4) Using an emotional approach in providing health services to the family.

5) Community nurses socialize health protocols that need to be implemented by families at tourist attractions.

6) Provision of communication media, information and education (kie) regarding the prevention and control of COVID-19 in strategic locations in every tourist spot.

7) Improving the quality and role of community nurses as supervisors of families at each tourist location.

The hierarchy of the criteria and alternative policies can be seen in Figure 2. This figure explains that the purpose of the hierarchy is to determine the family nurse strategy for tourism health during the COVID-19 pandemic which is a priority based on health, family and tourism criteria with 7 alternatives. policies or strategies that have the potential to be implemented.

Asman, A., Asman, A., \& Dewi, A. K. (2021). Community nursing strategies for tourism health families during COVID-19 pandemic. International Journal of Health Sciences, 5(3), 224-231. https://doi.org/10.53730/ijhs.v5n3.1449 


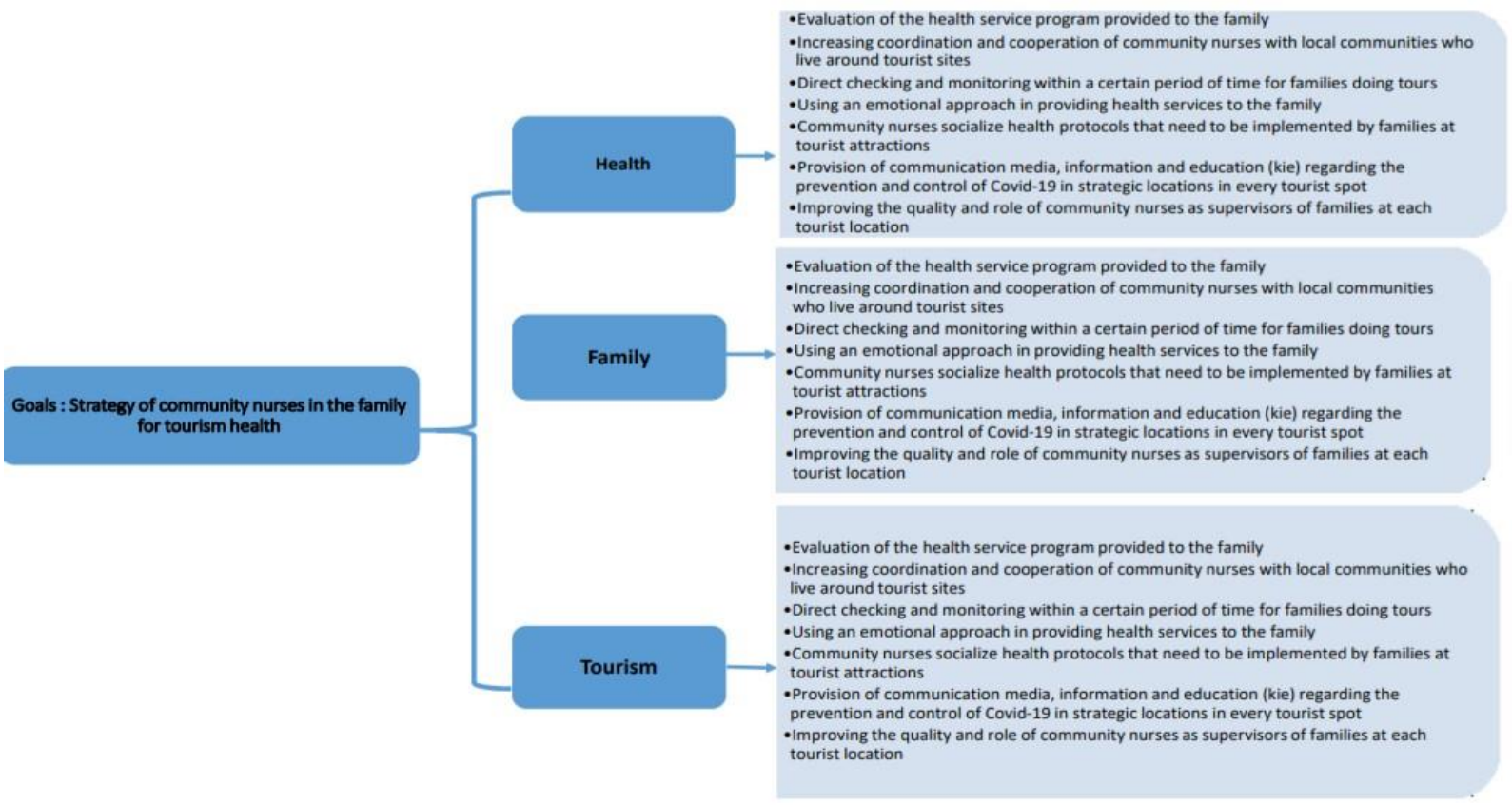

Figure 2. Hierarchy of community nurse strategies in families

The results of the pairwise assessment between policy alternatives carried out by the expert resulted in three policy priorities. This means, of the seven existing policy alternatives, what the government can do in priority to implement is the alternative that has the highest weight, namely three policies or strategies. The priority strategies or policies based on Figure 3 are as follows:

1) Provision of communication, information and education (IEC) media regarding the prevention and control of COVID-19 in strategic locations in every tourist spot (37\%). This strategy can be implemented in the following steps:

a) Designing and designing media in various forms that are effective and in accordance with the needs of the target community by choosing the determination of images, covers and paying attention to aesthetics that can attract people's attention.

b) Evaluating the IECs that have been produced and those that have been distributed. The extent to which benefits the community and impacts on changes in attitudes and behavior in society.

c) Develop modules, manuals, and posters that are easy to understand and apply that can be used by families.

d) Designation of field officers with the aim of promoting the prevention and control of COVID-19.

2) Direct checking and monitoring within a certain period of time for families doing tours (22\%). This strategy can be implemented in the following steps:

a) Tourists are required to report to the RT head and community nurse that they will and have taken a tour.

b) Tourists are required to bring a rapid test as proof that tourists are not indicated by COVID-19.

c) Facilitating health protocols for tourists who will enter tourist areas.

d) Assignment of field assignments with the aim of monitoring tourists in order to follow health protocols. 
3) Community nurses socialize health protocols that need to be implemented by families at tourist sites $(16.2 \%)$. This strategy can be implemented in the following steps:

a) Formation of community nurses who are experienced and have expertise or knowledge about COVID-19.

b) Community nurses disseminate information about health protocols that must be applied by every family when outside the home, especially in crowded places.

c) Community nurses are assigned to accompany each family for which they are responsible.

d) The community nurse will record or check periodically for family members who return from traveling.

Dymarnic sensitivity for nodes below : Goals : Strategy of community nurses farnily for tourism health

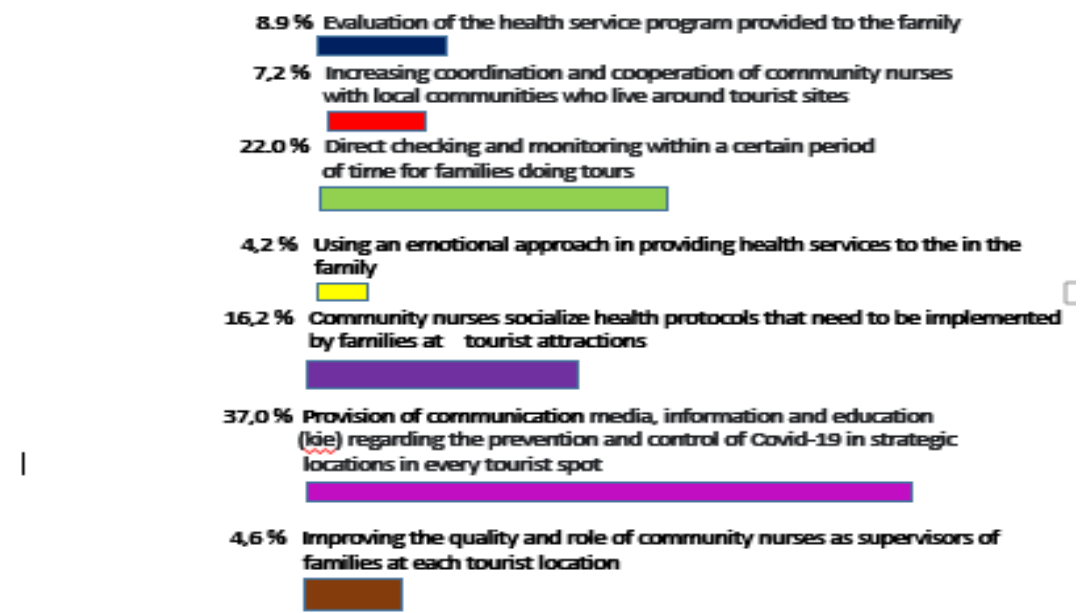

Figure 3. Policy priorities

These three policy priorities or strategies can be applied with the cooperation between the government, especially the Health Office in assigning community nurses, the community represented by the head of the RT and the head of the household, and the Tourism Office. If cooperation is not well established, then families in traveling can increase the risk of spreading COVID-19.

\section{Conclusion}

The strategy of community caring for the family for tourism health during the COVID-19 pandemic which is a priority based on the criteria for health, family and tourism in sequence which consists of providing communication, information and education (IEC) media regarding the prevention and control of COVID-19 in strategic locations in every tourist spot; direct checking and monitoring within a certain period of time for families conducting tours; community nurses socialize health protocols that need to be implemented by families in tourist attractions; evaluating the health service program provided to the family; increasing coordination and cooperation of community nurses with local communities living around tourist sites; improving the quality and role of community nurses as supervisors of families at each tourist location; and using an emotional approach in providing health services to families.

Acknowledgments

We are grateful to two anonymous reviewers for their valuable comments on the earlier version of this paper.

Asman, A., Asman, A., \& Dewi, A. K. (2021). Community nursing strategies for tourism health families during COVID-19 pandemic. International Journal of Health Sciences, 5(3), 224-231. https://doi.org/10.53730/ijhs.v5n3.1449 


\section{References}

Asman, A., \& Asman, A. A. (2021). Relationship Of Family Knowledge About Prevention Of Decubitus With The Event Of Decubitus In Patients Total Care In The Neurology Room Of Pariaman Hospital RSUD. Journal Scientific Of Mandalika (JSM) e-ISSN 2745-5955, 2(7 Juli), 305-311.

Asman, A., \& Fatimah, S. (2020). Implementation of Universal Awareness in Management of Hospital Environment as A Business for Prevention of Nosocomial Infections in Pariaman Regional General Hospital Science and Environmental Journals for Postgraduate Vol. 2 No. 2 (pp. 14-23) June 2020p_ISSN 26555085e_ISSN 2655-5239.

Asman, A., Asman, A., \& Alfina, R. (2020). The Model of Trauma Healing Policy for the Tsunami Disaster Mitigation in Padang, Indonesia. Sumatra Journal of Disaster, Geography and Geography Education, 4(2), 212-219.

Berger, F. R. (2020). The future of steelmaking-How the European steel industry can achieve carbon neutrality. Roland Berger GMBH.

Betony, K., \& Yarwood, J. (2013). What exposure do student nurses have to primary health care and community nursing during the New Zealand undergraduate Bachelor of Nursing programme?. Nurse Education Today, 33(10), 1136-1142. https://doi.org/10.1016/j.nedt.2012.12.007

Budiyanti, E. (2020). Dampak virus corona terhadap sektor perdagangan dan pariwisata Indonesia. Info Singkat $X I I,(4)$.

Campbell, A. M. (2020). An increasing risk of family violence during the Covid-19 pandemic: Strengthening community collaborations to save lives. Forensic science international: reports, 2, 100089. https://doi.org/10.1016/j.fsir.2020.100089

Clase, C. M., Fu, E. L., Ashur, A., Beale, R. C., Clase, I. A., Dolovich, M. B., ... \& Carrero, J. J. (2020, July). Forgotten technology in the COVID-19 pandemic. Filtration properties of cloth and cloth masks: a narrative review. In Mayo Clinic Proceedings. Elsevier. https://doi.org/10.1016/j.mayocp.2020.07.020

Dredge, D., Phi, G. T. L., Mahadevan, R., Meehan, E., \& Popescu, E. (2019). Digitalisation in Tourism: In-depth analysis of challenges and opportunities.

Dryglas, D., \& Salamaga, M. (2018). Segmentation by push motives in health tourism destinations: A case study of Polish spa resorts. Journal of Destination Marketing \& Management, 9, 234-246. https://doi.org/10.1016/j.jdmm.2018.01.008

Foddai, A., Lubroth, J., \& Ellis-Iversen, J. (2020). Base protocol for real time active random surveillance of coronavirus disease (COVID-19)-Adapting veterinary methodology to public health. One health, 9, 100129. https://doi.org/10.1016/j.onehlt.2020.100129

Gunter, R. L., Fernandes-Taylor, S., Rahman, S., Awoyinka, L., Bennett, K. M., Weber, S. M., ... \& Kent, K. C. (2018). Feasibility of an image-based mobile health protocol for postoperative wound monitoring. Journal of the American College of Surgeons, 226(3), 277-286. https://doi.org/10.1016/j.jamcollsurg.2017.12.013

Hussin, D. A., Samah, M. A. A., Suhaimi, A. A., \& Kamarudin, M. K. A. (2021). A study on knowledge, attitude and practice of COVID-19 pandemic among the residents. International Journal of Health Sciences, 5(2), 177-188.

Jansen, P. G., Kerkstra, A., Abu-Saad, H. H., \& Van Der Zee, J. (1996). The effects of job characteristics and individual characteristics on job satisfaction and burnout in community nursing. International journal of nursing studies, 33(4), 407-421. https://doi.org/10.1016/0020-7489(95)00060-7

Kim, S. W., \& Su, K. P. (2020). Using psychoneuroimmunity against COVID-19. Brain, behavior, and immunity, 87, 4-5. https://doi.org/10.1016/j.bbi.2020.03.025

Kissler, S. M., Tedijanto, C., Goldstein, E., Grad, Y. H., \& Lipsitch, M. (2020). Projecting the transmission dynamics of SARS-CoV-2 through the postpandemic period. Science, 368(6493), 860-868.

Latifah, S. (2005). Basic Principles of Analytic Hierarchy Process. Department of Foresty, Faculty of Agriculture, University of North Sumatera.

Lisbet, L. (2020). Penyebaran COVID-19 dan Respons Internasional. Jurnal Bidang Hubungan Internasional Info Singkat: Kajian Singkat terhadap Isu Aktual dan Strategis, 12 (5), 8.

Marimin. (2005). Techniques and application of decision-making compound criteria, Grasindo: Jakarta.

Mufti, R., R. (2020). Tourism will take at least a year to recover from COVID-19 outbreak: Economists. The Jakarta Post. 6 April 2020.

Ningsih, S., Ismail, D., \& Indriani, I. (2021). Study protocol: relationship between parenting patterns and diet with nutritional status of toddlers during COVID-19 pandemic. International Journal of Health Sciences, 5(2), 128-134. 
Putri, Y. P., Barlian, E., Dewata, I., \& Al Tanto, T. (2018). Arahan Kebijakan Mitigasi Bencana Banjir Bandang di Daerah Aliran Sungai (DAS) Kuranji, Kota Padang. Program Pasca Sarjana Konsentrasi Pendidikan Geografi, Universitas Negeri Padang 2Loka Riset Sumber Daya dan Kerentanan Pesisir, BRSDM KKP.

Ratiu, M. P., \& Purcarea, I. M. (2015). Digital Tourism on the Way to Digital Marketing Success. Holistic Marketing Management Journal, 5(2), 30-37.

Saaty, T. L. (1993). Decision For Leaders, Analytical Hierarchy Process for Decision Making in Complex Situations. Management Series, (134).

Sayili, M., Akca, H., Duman, T., \& Esengun, K. (2007). Psoriasis treatment via doctor fishes as part of health tourism: A case study of Kangal Fish Spring, Turkey. Tourism Management, 28(2), 625-629. https://doi.org/10.1016/j.tourman.2006.08.010

Swarjana, I. K., SKM, M., \& Bali, S. T. I. K. E. S. (2015). Metodologi Penelitian Kesehatan [Edisi Revisi]: Tuntunan Praktis Pembuatan Proposal Penelitian untuk Mahasiswa Keparawatan, Kebidanan, dan Profesi Bidang Kesehatan Lainnya. Penerbit Andi.

Tetro, J. A. (2020). Is COVID-19 receiving ADE from other coronaviruses?. Microbes and infection, 22(2), 72-73. https://doi.org/10.1016/j.micinf.2020.02.006

UNWTO. (2020a). Impact assessment of the COVID-19 outbreak on international tourism. UN World Tourism Organization.

UNWTO. (2020b). Supporting Jobs And Economies Through Travel \& Tourism: A Call for Action to Mitigate the Socio-Economic Impact of COVID-19 and Accelerate Recovery. UN World Tourism Organization. 1 April 2020.

\section{Biography of Authors}

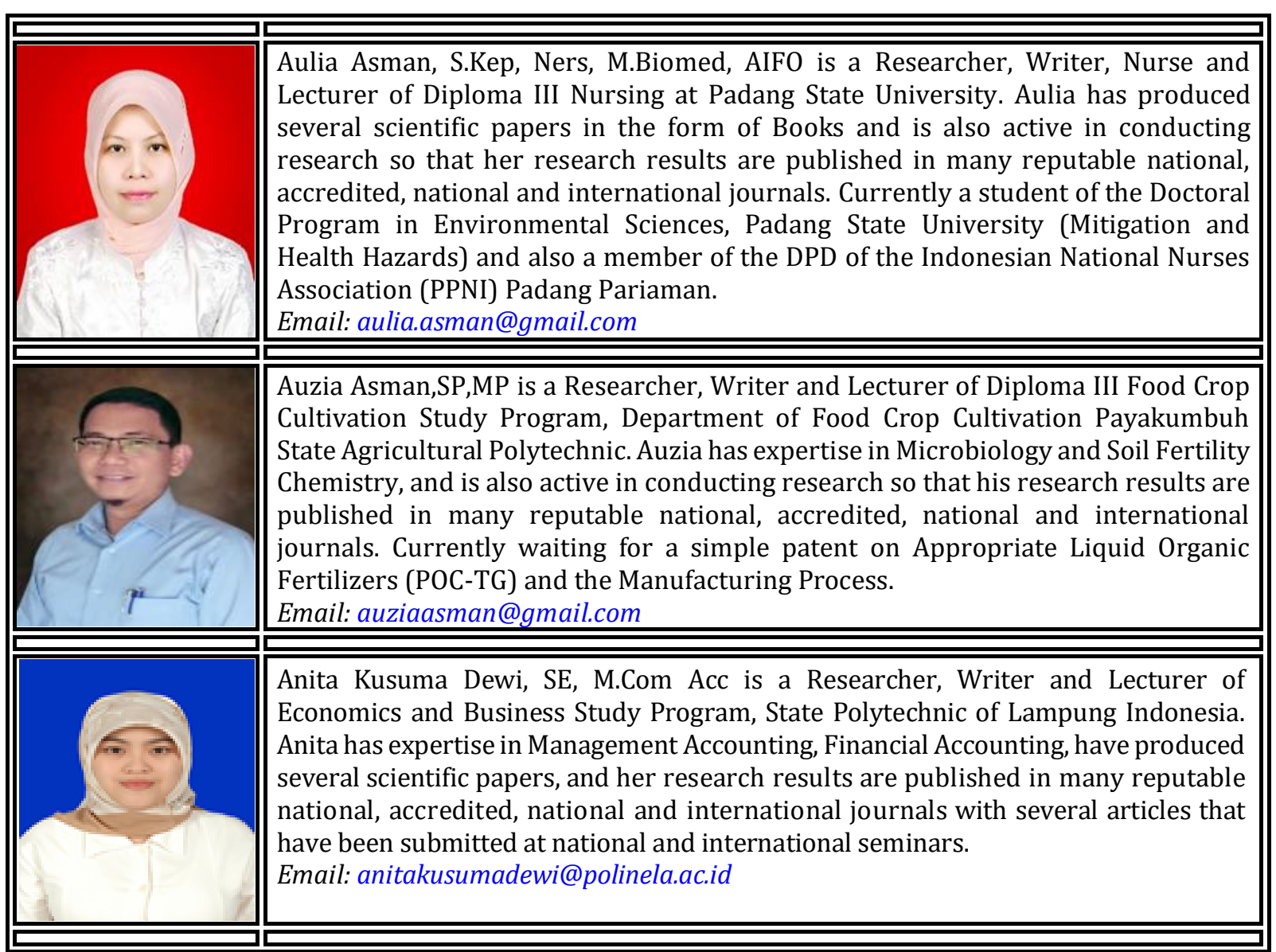

Asman, A., Asman, A., \& Dewi, A. K. (2021). Community nursing strategies for tourism health families during COVID-19 pandemic. International Journal of Health Sciences, 5(3), 224-231. https://doi.org/10.53730/ijhs.v5n3.1449 